\title{
Preserving treatments effect on the physicochemical properties of the plantain stored at an ambient temperature
}

\author{
René K. Dongo, Emmanuel Dick, Sorho Fatogoma, Brahima Camara, Daouda Kone
}

\author{
Laboratory of Plant Physiology, UFR Biosciences, University of Cocody-Abidjan
}

\begin{abstract}
The preservation of fruits and vegetables allows to avoid the post-harvest losses. Their keeping in freshness and in acceptable food value remains a concern for the specialists. Within the context of our work, several methods were tested and evaluated for the plantain. The factors with which these organs were subjected to, are chemical substances which are gibberellic acid GB and imazalil sulphate IZ; polyethylenic thickness film 100 $\mu$ m (P100). During the storage which lasted 28 days, physical measurements (weight, color of peel and pulp, firmness of the whole fruit) and biochemical ones (soluble reducing sugars) were taken. The results permit to conclude that plantain subjected to all the treatments (P100, GB, GB.P100, IZ and IZ.P100) as well as control (TM) have different behaviors at $28 \pm 2{ }^{\circ} \mathrm{C}$. Fruits remained green for IZ.P100 and P100. On the other hand, with TM, GB, GB.P100 and IZ, some plantains ripen and others start their ripening very later at $28 \pm 2{ }^{\circ} \mathrm{C}$. Packaging slows down the ripening of the plantain.
\end{abstract}

Keywords: Plantain, preservation, ripening, chemical substance

\section{INTRODUCTION}

The world production of bananas and plantains (and the other types of this fruit) is estimated at 88 million tons per year (Bakry et al., 2002). Côte d'Ivoire produces an average of 1510778 tons of plantain a year (FAO, 2007). This production depends on a season marked by a period of abundance which goes from September to April, followed by a period of shortage which extends from May to August (Kuperminc, 1998; Sery, 1988). During that period of shortage, the rise in the average prices of plantain on the markets reaches levels which make it inaccessible for the major party of the households. The preservation treatments which makes it possible to limit the post-harvest losses could reduce this periodic deficit.

Face to the thorny problem of the human consumption of food in the developing countries, it is pressing to define simple and cheaper methods for the preservation of agricultural food products like plantain. The difficulties of plantains preservation make the fruits, while ripening at the ambient temperature, undergo depreciation and also qualitative and quantitative degradations along the distribution chain (Chia and Huggins, 2003).

The objective to foresee solutions about the problems of preservation led to the use of chemical substances like the gibberellins, delayer of ripening or sulphate of imazalil, reducer of rotting. These compounds were associated packing out of polyethylene bag relatively thick which was used to create microenvironment rich in $\mathrm{CO}_{2}$ and low in $\mathrm{O}_{2}$ around the fruit (Kader, 2002; Dick, 2006). The plantains treated or not, were stored at the ambient temperature $\left(28 \pm 2^{\circ} \mathrm{C}\right)$. The organoleptic properties of the fruits were appreciated through the evaluation of the colour, the loss of weight, firmness and the content in soluble and reducing sugars.

The purpose of the study is to test the efficacy of various treatments implemented to the plantain in order to adopt the best methods of preservation.

\section{MATERIAL AND METHODS}

Plant material: The plant material is the plantain fruit harvested from cultivar Corne 1 (Musa AAB). This variety was selected because it is the most widespread plantain in Côte d'Ivoire, and thus most easily found. Fruits were obtained from the peasant orchards of M'Pouto, village located in the East suburbs of Abidjan, at ten kilometers from the University of Cocody-Abidjan. They were collected physiologically mature, 85 to 95 days after the emergence of the bud, when the apex of the fruits has obviously blackened (Dadzie, 1998). The fruits of the first two hands starting from the peduncle of the bunch were weighed using a balance (Sartorius type) of $\pm 0.01 \mathrm{~g}$ average precision. Those whose weight lies between 320 and $370 \mathrm{G}$ were kept.

Treatment conditions: Within three hours after harvest, the selected fruits were rinsed with tap water and classified in 6 batches of 10 fruits: 
batch 1 - control (TM) made up of plantain not having undergone any treatment and exposed to the storage temperature $\left(28 \pm 2{ }^{\circ} \mathrm{C}\right)$;

batch 2 - plantains are sealed individually in a polyethylene bag of $100 \mu \mathrm{m}$ of thickness having a volume of $1650 \mathrm{ml}$ and a total exchange surface of $800 \mathrm{~cm}^{2}$ (P 100);

batch 3 - plantains are soaked in a gibberellic acid solution of $100 \mu \mathrm{M}$ during 5 min (GB);

batch 4 - plantains are treated with the gibberellic acid and bagged like previously. (GB.P100);

batch 5 - plantains are soaked in an imazalil sulphate solution (40 g/L) for $5 \mathrm{~min}$. (IZ);

batch 6 - plantains are treated with imazalil sulphate and bagged (IZ.P100).

The batches of fruits were then stored on shelves at ambient temperature $\left(28 \pm 2{ }^{\circ} \mathrm{C}\right)$ then observed for 28 days. Three repetitions were made per treatment.

Color of the peel and pulp of banana fruits: The color of the peel was estimated while referring on a colorimetric scale established on banana (Musa AAA) of the Poyo variety (IRFA, 1980). This scale is graduated from 1 to 7 , that is to say immature green to yellowish before appearance of necrotic spots.

The color of the pulp was given on a cross section of the fruit, by comparison with a colorimetric scale varying from 2 to 16 , that is to say white-cream coloured to orange (IRFA, 1980).

Weight loss and firmness: During storage, the fruits were weighed again in order to estimate the weight losses.

Firmness was measured by evaluating the penetrometric hardness of the whole fruit.

The principle of the method consists in implementing a penetrometer of the "crossbow" type in 3 points of the median area of the fruit forming an angle of $120^{\circ}$. The thrust force of the cylindrical probe of the instrument (length $=8 \mathrm{~mm}$, diameter $=3 \mathrm{~mm}$ ) in the banana plantain, was measured using a calibrated spring. The values were expressed in $\mathrm{kg}$.

Contents of soluble and reducing glucids of pulp: The soluble and reducing glucids were mesured by using the 3,5-dinitrosalicylic acid (DNS). Two grams of pulp were mixed in a mortar with $5 \mathrm{ml}$ of $80 \%$ ethanol. After centrifugation at $5000 \mathrm{rpm}$, the supernatant $\left(S_{1}\right)$ was collected in a graduated flask. The base was given in suspension with $5 \mathrm{ml}$ of distilled water and centrifuged again like previously. The supernatant obtained $\left(S_{2}\right)$ was joined to $S_{1}$ then the unit was adjusted to a final volume of $20 \mathrm{ml}$ with distilled water.

Analyses were performed by comparison with a range standard made up from a stock solution of glucose $50 \mu \mathrm{g} / \mathrm{ml}$. The standard and test tubes were prepared each one with respectively $1 \mathrm{ml}$ of glucose and $1 \mathrm{ml}$ of extract, $1 \mathrm{ml}$ of DNS and $1 \mathrm{ml}$ of distilled water. The preparations were plunged in boiling water during $5 \mathrm{~min}$. then cooled under water jet and supplemented to $5 \mathrm{ml}$ with distilled water. The D.O. was measured with spectrophotometer (Spectronic 21D) at the wavelength of $540 \mathrm{~nm}$. The results were expressed in $\mathrm{mg} / \mathrm{g}$ of fresh matter.

Statistical analysis: Data were forwarded to analysis of variance (ANOVA) using STATISTICA 6.0 software. The significant differences between homogeneous groups were determined by the test of Newmann-Keuls to probabilities lower than 0.05.

\section{RESULTS}

Color of the peel and pulp: The treatments carried out made it possible to note three groups of plantains according to the reaction observed on the peel (fig. 1). A first group consisted of the batches TM, GB and IZ whose fruits ripen with respectively on the $14^{\text {th }}$ and $28^{\text {th }}$ day of storage, with an intense yellow color (index $=6$ ) and yellow-orange color with some necrotic spots (index $=7$ ). A second group only made up of batch GB.P100 is distinguished from the precedent by a deceleration of the yellowing of the peel of the fruits. Thus, from the 14th day when the plantains still have a green color (index $=2$ ), those gradually turn into intense yellow (index $=6$ ). A third group contains batches P100 and IZ.P100 with fruits which remain green (index $=2$ ) during the 28 days of storage at the ambient temperature. These results are confirmed by the observations on the pulp (fig. 2). Thus, the plantains of the batches TM, GB and IZ have an identical pulp color which, from the harvest of the fruits to the 28th day of storage turns from cream-color (index $=2$ ) into yellow-orange (index = 12 ) or orange (index $=14$ ). The pulp of the fruits of GB.P100 notably changes color only from the $14^{\text {th }}$ day until the $28^{\text {th }}$ day while passing from white salmon (index $=4$ ) to yellow-orange (index $=12$ ). The fruits of the group of batches P100 and IZ.P100 have a pulp which hardly changes from harvest to the $28^{\text {th }}$ day of storage; the aforementioned passes from the cream-color (index $=2$ ) to the white salmon (index= 4). 


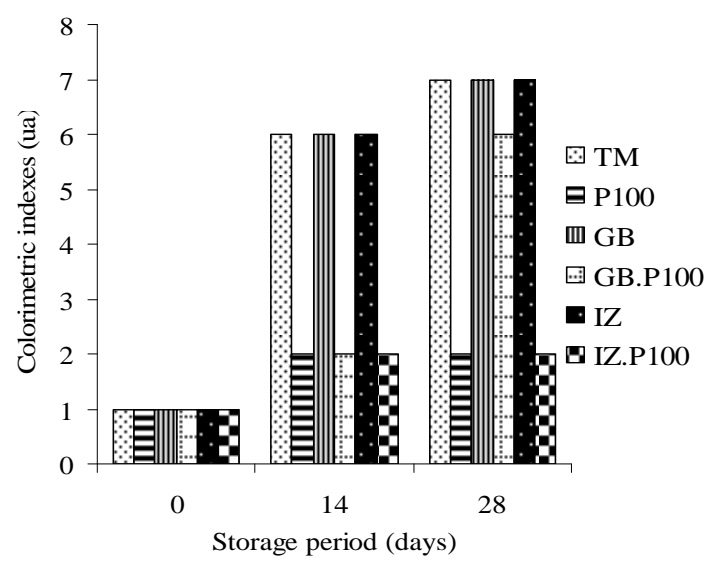

Fig 1: indices colorimétriques de l'épicarpe des bananes plantain entreposées à la température ambiante $\left(28 \pm 2^{\circ} \mathrm{C}\right)$, après traitements de conservation

$\mathrm{TM}$ : témoin ; $\mathrm{P} 100$ : polyéthylène ; $\mathrm{GB}$ : acide gibbérellique; GB.P100 : acide gibbérellique + polyéthylène ; IZ: sulfate d'imazalii; IZ.P100 : sulfate d'imazalil + polyéthylène

Figure 1: colorimetric indexes of plantain peel at the ambient temperature $\left(28 \pm 2{ }^{\circ} \mathrm{C}\right)$, after preservation treatments

TM: control; P100: polyethylene; GB: gibberellic acid; GB P 100: gibberellic acid + polyethylene; IZ: imazalil sulphate; IZ. P100: imazalil sulphate + polyethylene

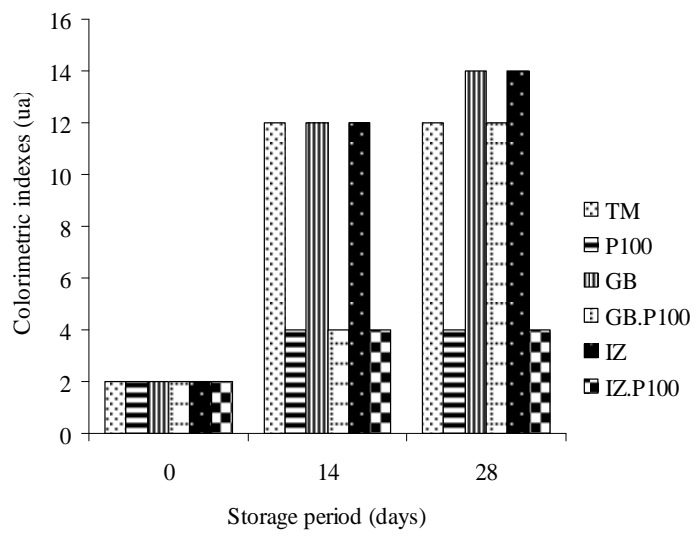

Fig 2 : indices colorimétriques de la pulpe des bananes plantain entreposées à la température ambiante $(28 \pm 2$ ${ }^{\circ} \mathrm{C}$ ), après traitements de conservation

TM : témoin ; P100: polyéthylène; GB : acide gibbérellique; GB.P100 : acide gibbérellique + polyéthylène ; IZ: sulfate d'imazalil; IZ.P100 : sulfate d'imazalil + polyéthylène

Figure 2: colorimetric indexes of plantain pulp at the ambient temperature $\left(28+2{ }^{\circ} \mathrm{C}\right)$, after preservation treatments

TM: control; P100: polyethylene; GB: gibberellic acid; GB P 100: gibberellic acid + polyethylene; IZ: imazalil sulphate; IZ. P100: imazalil sulphate + polyethylene

Weight loss and firmness: The weight loss of the plantains at the ambient temperature makes it possible to gather the batches in two groups, except for the control, according to whether the fruits are packed in polyethylene or only treated by chemicals (fig. 3). The untreated fruits of the control batch (TM) have, at the end of storage, the most important loss of weight. The recorded value is $28.33 \%$ at the $28^{\text {th }}$ day. The group of the packed fruits of the batches P100, GB.P100 and IZ.P100 have the weakest losses of the weight with values statistically identical varying from 0.92 (IZ.P100) to $1.56 \%$ (GB.P100) at the end of the experiment. On the other hand, the fruits only treated by chemical compounds of the group of batches GB and IZ have, at the $28^{\text {th }}$ day, intermediate pondered losses of the two preceding groups. The values which are not significantly different vary in this group between $16.34 \%$ (IZ) and $17.07 \%$ (GB).

The evaluation of the firmness of the whole fruits (fig. 4) has permitted to gather them according to the time of storage. Four groups were defined on the $14^{\text {th }}$ day of storage. In the first group made up of the batch IZ.P100, the firmness of the fruits increased to a significant degree. It passed from 4.30 (J0) to 4.65 (J4). The $2^{\text {nd }}$ group is consisted of the batches $P 100$, GB.P100 and IZ. The firmness of the fruits of this group did not vary to a significant degree compared to the starting firmness (J0). The $3^{\text {rd }}$ group (GB) consists of fruits whose firmness was intermediate compared to group 1 and 2 . The $4^{\text {th }}$ group (TM) consists of fruits whose firmness fell from 4.3 to 0.95 $\mathrm{kg}$.

After 28 days of storage, the evaluation of the firmness of the whole fruits made it possible to define three groups of batches. The first group is consisted of the batches P100 and IZ.P100 whose firmness is superior or equal to $4.3 \mathrm{~kg}$. The second group (GB.P100 and IZ) has an average firmness around 3 $\mathrm{kg}$. The third group (TM and GB) is characterized by the lowest firmness of the fruits $(0.5 \mathrm{~kg})$.

Contents in soluble and reducing sugars: The content in soluble and reducing sugars of the pulp of plantain stored at the ambient temperature $\left(28 \pm 2^{\circ}\right.$ C), increased according to the treatment (fig. 5). On day 0 , all the plantains have the same content in soluble and reducing sugars whatever the treatment. Fourteen days after the storage the content in soluble and reducing sugar of arise brutally for the batches TM, GB, GB.P100 and IZ and weakly for P100 and IZ.P100. Then at the $28^{\text {th }}$ day of storage, the accumulation of soluble and reducing sugars in the pulp of plantain is very weak in the batches P100 and IZ.P100 and high in the others. 
Agric. Biol. J. N. Am., 2011, 2(5): 761-766

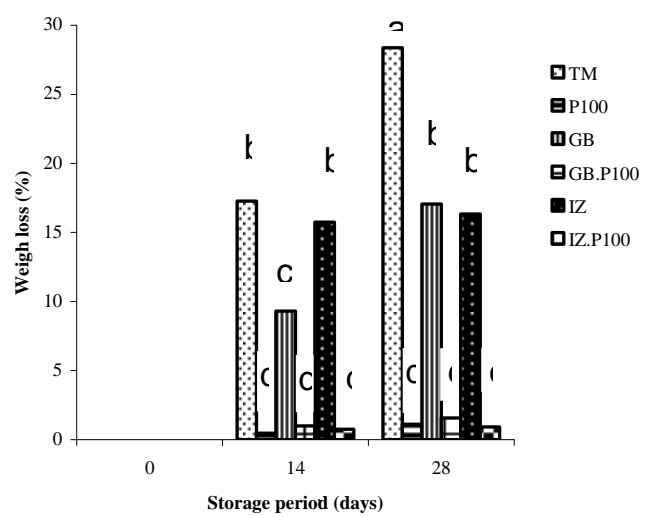

Fig 3 : perte de poids des bananes plantain entreposées à la température ambiante $\left(28 \pm 2^{\circ} \mathrm{C}\right)$, après traitements de conservation

$\mathrm{TM}$ : témoin ; $\mathrm{P} 100$ : polyéthylène; $\mathrm{GB}$ : acide gibbérellique; GB.P100: acide gibbérellique + polyéthylène ; IZ: sulfate d'imazalii; IZ.P100 : sulfate d'imazalil + polyéthylène

Les histogrammes affectés des mêmes lettres différentes ne sont pas significativement différents

Figure 3: weight loss of plantain stored at the ambient temperature $\left(28 \pm 2{ }^{\circ} \mathrm{C}\right)$, after preservation treatments

TM: control; P100: polyethylene; GB: gibberellic acid; GB P 100: gibberellic acid + polyethylene; IZ: imazalil sulphate; IZ. P100: imazalil sulphate + polyethylene

Histograms with the same letters are not significantly different

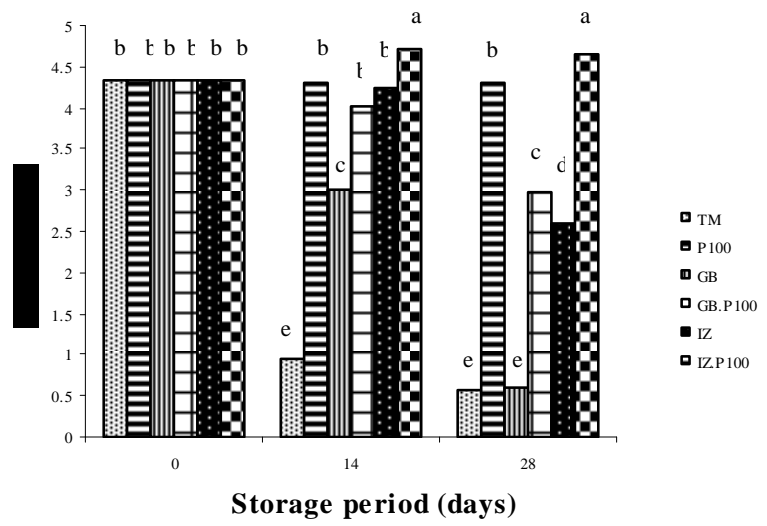

Fig 4 : fermeté des bananes plantain entreposées à la température ambiante $\left(28 \pm 2{ }^{\circ} \mathrm{C}\right)$, après traitements de conservation

TM : témoin ; P100 : polyéthylène ; GB : acide gibbérellique; GB.P100: acide gibbérellique + polyéthylène; IZ: sulfate d'imazalii; IZ.P100 : sulfate d'imazalil + polyéthylène

Les histogrammes affectés des mêmes lettres différentes ne sont pas significativement différents

Figure 4: firmness of plantain stored at the ambient temperature $\left(28+2{ }^{\circ} \mathrm{C}\right)$, after preservation treatments

TM: control; P100: polyethylene; GB: gibberellic acid; GB P 100: gibberellic acid + polyethylene; IZ: imazalil sulphate; IZ. P100: imazalil sulphate + polyethylene

Histograms with the same letters are not significantly different

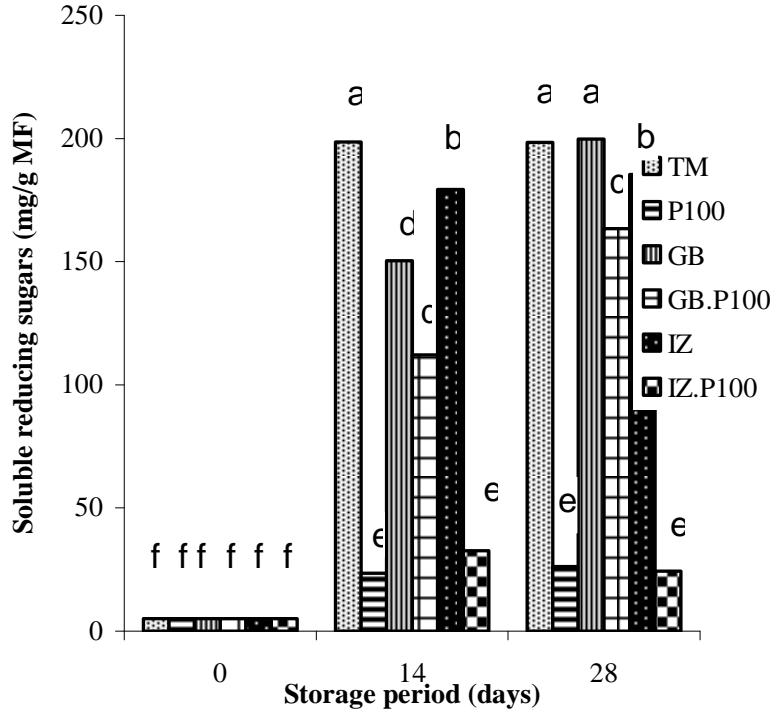

Fig 5 : teneurs en glucides solubles et réducteurs de la pulpe des bananes plantain entreposées à la température ambiante $\left(28 \pm 2^{\circ} \mathrm{C}\right)$, après traitements de conservation

TM : témoin ; $\mathrm{P} 100$ : polyéthylène ; $\mathrm{GB}$ : acide gibbérellique; GB.P100 : acide gibbérellique + polyéthylène ; IZ: sulfate d'imazalil; IZ.P100 : sulfate d'imazalil + polyéthylène

Les histogrammes affectés des mêmes lettres différentes ne sont pas significativement différents

Figure 5: soluble reducing sugars content of plantain pulp stored at ambient temperature $\left(28 \pm 2{ }^{\circ} \mathrm{C}\right)$, after preservation treatments TM: control; P100: polyethylene; GB: gibberellic acid; GB P 100: gibberellic acid + polyethylene; IZ: imazalil sulphate; IZ. P100: imazalil sulphate + polyethylene

Histograms with the same letters are not significantly different DISCUSSION

At ambient temperature, the plantains of the untreated control batch undergo the ripening of which the most obvious signs are summarised in a loss of the green colour of the peel, a softening of the fruit which acquires a sweeter taste while developing a light specific flavour. Concerning the yellowing of the peel and pulp, the same observations as that of the control batch are also made in batches $\mathrm{GB}, \mathrm{IZ}$ and GB.P100 with however in this last case, a persistence of the green colour of the peel 14 days after the beginning of storage. This effect favourable to the conservation seems to be due, for GB.P100 to the packaging of the fruits. That confirms the results obtained by George and Marriott (1983) that showed that the gibberellic acid has favourable effect over the duration of "green life" of the plantains only under the conditions of an important relative humidity, as it is the case inside the packaging bags. The defect of effectiveness of gibberellic acid and the imazalil sulphate solutions in the other batches could be due 
either, to a weak infiltration in the tissues of the fruits, or to an insignificant protective effect of the chlorophyll. On the other hand, the fruits of the P100 and IZ.P100 batches except for the development of fungi on the peduncle practically remain in the same state during storage, whether it is of the peel or pulp. These observations are to be connected to the use of the polyethylene sachets whose properties of selective permeability to atmospheric gases contribute to ensure by respiratory exchanges, important rates of $\mathrm{CO}_{2}$ and weak rates of $\mathrm{O}_{2}$ inside packages (Varoquaux et al., 2002; Elkashif et al., 2005). The obtained atmospheres, and particularly the strong contents in $\mathrm{CO}_{2}$ inhibit the synthesis of ethylene, just as the respiratory activity of fruits (Happi Emaga et al., 2008); what strongly slows down ripening. At $25{ }^{\circ} \mathrm{C}$ and under the same experimental conditions, the gas composition in the packaging bags of the plantains was estimated at approximately $7 \%$ of $\mathrm{CO}_{2}$ and $5 \%$ of $\mathrm{O}_{2}$ (Dick, 2006). The loss of weight and firmness is more important in the control batch (TM) than in the other batches. The gibberellic acid and the imazalil sulphate only seem to delay, at different periods, the observed phenomena. On the other hand, except the firmness of the plantains of GB.P100, all the packed fruits have, whatever the treatment carried out, a weak softening and weight loss on the $28^{\text {th }}$ day of storage at the ambient temperature. During ripening, the softening depends, as Smith (Smith, 1989) thinks it, of three events. The first relates to the starch in pulp. Indeed, this macromolecule which undoubtedly has a structural function in the cells, waste out in simple sugars. The second is connected with the degradation of the cellular walls due to the solubilization of the pectic substances and also to the enzymatic destruction of cellulose. The third possible process could be an osmotic migration of the water of the pericarp towards pulp. That would affect the turgescence of the pericarp just like the transpiration. This change in the hydric statute of the fruit would also contribute to its loss of weight (Smith et al., 1990). In addition, the recrudescence of the metabolic activities during the climacteric crisis of ripening could support a considerable matter loss (organic substrates, water vapour in particular) which would result in a weight decrease. Concerning the packed plantains, the limitation of transpiration inside the closed bags associated to the absence of ripening contribute to maintain constant the weight and firmness for all the duration of storage at the ambient temperature.
The accumulation of soluble and reducing sugars, intense in the pulp of the plantains of batches TM, GB and IZ, is less in that of the packed fruits, except GB.P100. In this case, a delaying effect of the synthesis of soluble and reducing sugars rather seems to be due to polyethylene bagging. This observation confirmed in batches P100 and IZ.P100, is undoubtedly due to an increase in the $\mathrm{CO}_{2}$ rate and an increasing scarcity of $\mathrm{O}_{2}$ inside the sachets, by the means of the respiratory exchanges. That causes, in addition to inhibiting the synthesis of ethylene by reducing the activity of the ACC oxidase (Pech et al., 1994) to limit the production of soluble sugars by the inactivation of the enzymes of the carbon metabolism (Beaudry et al., 1994; Hubbard et al., 1990).

\section{CONCLUSION}

The gibberellic acid and imazalil sulphate do not have a noticeable effect on the preservation of the plantains fruits, except for a transitory deceleration of ripening relatively to the loss of weight and firmness. The combination of polyethylene films with the employed chemical substances does not significantly improve the effectiveness of packing.

On the other hand, the use of the polyethylene bags 100 microns- thickness alone seems to be presented in the form of a not very expensive alternative to the refrigeration for the conservation of plantain at the ambient temperature over a period of approximately 4 weeks.

\section{REFERENCES}

Bakry F., Didier C., Ganry J., Le Bellec F., Lescot T., Pinon A., Rey J.Y., Teisson C. and Vannicre M. 2002. Les espèces fruitières. In : CIRAD (ed), Mémento de l'Agronome, Gret et Mae, Paris 960-974.

Beaudry R. M., Severson R. F., Black C. C. and Kays S. J. 1989. Bananas ripening implication of changes in glycolitic intermediate concentrations glycolitic and gluconeogenic carbon flux and fructose 2,6biphosphate concentration. Plant Physiol., 91, 14361444.

Chia C. L. and Huggins C. A. 2003. Bananas. Community Fact sheet BA-3(A) Fruit. Hawaii Cooperative Extension Service, CTAHR, University of Hawaii.

Dadzie B. K. 1998. Post-harvest characteristics of black Sigatoka resistant banana, cooking banana and plantain hybrids. Inibap Technical Guidelines, IPGRIINIBAP, Rome-Montpellier. 75 p.

Dick E. 2006. Contribution à l'étude de la physiologie du mûrissement, de l'entreposage et de la conservation de la banane plantain après récolte. Thèse de 
Agric. Biol. J. N. Am., 2011, 2(5): 761-766

Doctorat d'Etat, Physiologie post récolte. Université de Cocody-Abidjan, UFR Biosciences. Abidjan Côte d'Ivoire, $243 \mathrm{p}$.

Elkashif M. E., Elamin O. M. and Ali S. A. 2005. Effect of packaging method and storage temperature on quality and storability of four introduced banana clones. Gezira Journal of Agricultural Science, 3 (2), 185-195.

FA0, 2007. Organisation des Nations Unies pour l'Alimentation et l'Agriculture. Département Économique et Social. La Division de la Statistique.

Georges J. B and Marriot J. 1983. The effect of humidity in plantain ripening. Scientia Hortic. 21, 37-43.

Happi Emaga T., Wathelet B. and Paquot M. 2008. Changements texturaux et biochimiques des fruits du bananier au cours de la maturation. Leur influence sur la réservation de la qualité du fruit et la maîtrise de la maturation. Biotechnol. Agron. Soc. Environ. 12 (1): 89-98.

Hubbard N. L., Pharr D. M. and Huber S. C. 1990. The role of sucrose phosphate synthase in sucrose biosynthesis in ripening bananas and its relationship to the respiratory climacteric. Plant Physiol., 94, 201-208.

IRFA, 1980 : Institut de Recherches sur les Fruits et Agrumes. La qualité de la banane. La
Réglementat ion française et son Interprétation. 74 pp.

Kader A. A. 2002. Postharvest Technology of Horticultural Crops. $3^{\text {rd }}$ edition. Cooperative Extension, University of California, Division of Agriculture and Natural Resources. Publication 3311. $535 \mathrm{p}$

Kuperminc O. 1988. Saisonnalité et commercialisation de la banana plantain en Côte d'Ivoire. Fruits, 43 (6) : 359-368

Pech J. C., Balague C., Latche A. and Bouzayen M. 1994. Post harvest physiology of climacteric fruits: recent development in the biosynhesis and action of ethylene. Sci. Aliments, 14, 3-15.

Sery D.G. 1988. Rôle de la banane plantain dans l'économie ivoirienne. Fruits, 43 (2) : 73-78.

Smith N. J. S. 1989. Textural and biochemical changes during the ripening of banana. $\mathrm{PhD}$ Thesis, University of Nottingham.

Smith N. J. S., Segmour G. B., Jeger M. J. and Tuker G. A. 1990. Cell well changes in bananas and plantains. Acta Hortic. 269, 283-289.

Varoquaux P., Gouble B., Ducamp M. N. and Guy S. 2002. Procedure to optimize modified atmosphere packaging for fruit. Fruits. 57, 313-322. 